\title{
Phylogeographic history of the yellow-necked fieldmouse (Apodemus flavicollis) in Europe and in the Near and Middle East
}

\author{
J.R. Michaux, ${ }^{\mathrm{a}, \mathrm{b}, *}$ R. Libois, ${ }^{\mathrm{a}}$ E. Paradis, ${ }^{\mathrm{b}}$ and M.-G. Filippucci ${ }^{\mathrm{c}}$ \\ ${ }^{a}$ Unité de Recherches Zoogéographiques, Institut de Zoologie, Quai Van Beneden, 22, 4020 Liège, Belgium \\ b Laboratoire de Paléontologie-cc064, Institut des Sciences de l'Evolution (UMR 5554-CNRS), Université Montpellier II, \\ Place E. Bataillon, 34095, Montpellier Cédex 05, France \\ ' Dipartimento di Biologia, Università di Roma "Tor Vergata" Via della Ricerca Scientifica, 00133 Rome, Italy
}

Received 25 July 2003; revised 3 February 2004

Available online 15 April 2004

\begin{abstract}
The exact location of glacial refugia and the patterns of postglacial range expansion of European mammals are not yet completely elucidated. Therefore, further detailed studies covering a large part of the Western Palearctic region are still needed. In this order, we sequenced $972 \mathrm{bp}$ of the mitochondrial DNA cytochrome $b$ (mtDNA cyt b) from 124 yellow-necked fieldmice (Apodemus flavicollis) collected from 53 European localities. The aims of the study were to answer the following questions:

- Did the Mediterranean peninsulas act as the main refuge for yellow-necked fieldmouse or did the species also survive in more easterly refugia (the Caucasus or the southern Ural) and in Central Europe?

- What is the role of Turkey and Near East regions as Quaternary glacial refuges for this species and as a source for postglacial recolonisers of the Western Palearctic region?

The results provide a clear picture of the impact of the

quaternary glaciations on the genetic and geographic structure of the fieldmouse. This species survived the ice ages in two main refuges, the first one in the Italo-Balkan region; the second one in Turkey and the Near East regions. It is from the Balkan refuge that it recolonised all European regions at the end of the last glaciation. The Turkish and Near East populations are distinct from the European ones and they did not recolonise the Palearctic region probably because: (i) they were blocked by the Black Sea and the Caucasus, (ii) the long term presence of fieldmice populations in the Balkans prevented their expansion. These are genetically differentiated from the European and Russian ones and could be described as a particular subspecies. This result emphasises the importance of Turkey and the Near and Middle East regions as a refuge for Palearctic mammals.
\end{abstract}

(C) 2004 Elsevier Inc. All rights reserved.

Keywords: Apodemus flavicollis; Phylogeography; Mitochondrial DNA; Western palearctic region; Near east region

\section{Introduction}

Recent molecular phylogeographic studies in Europe suggest that the majority of temperate species of mammals survived the Quaternary glaciations in Mediterranean refugia such as the Iberian, the Italian, and the Balkan peninsulas (Hewitt, 1999, 2001; Michaux et al., 2003; Taberlet et al., 1998). From these regions, they recolonised northern Europe at the end of the last

\footnotetext{
${ }^{*}$ Corresponding author. Fax : +32-43-66-59-45.

E-mail address: Johan.Michaux@ulg.ac.be (J.R. Michaux).
}

ice age, about 16,000 years ago (Hewitt, 2001; Michaux et al., 2003). However, some authors consider that this model of exclusively southern European glacial refugia is not universal and that some species such as the brown bear (Ursus arctos) (Taberlet et al., 1998) or different small mammal species (Clethrionomys glareolus, Sorex minutus, and Sorex araneus, Bilton et al., 1998; Microtus arvalis, Jaarola and Searle, 2002; Microtus oeconomus, Brunhoff et al., 2003) also survived in more easterly refugia (the Caucasus or the southern Urals) and in Central Europe. Nevertheless, in order to find the exact location of glacial refugia and to elucidate the patterns of postglacial range expansion of 
European mammals, further detailed studies covering a large part of the Western Palearctic region are still needed.

Moreover, to the exception of some data obtained on the hedgehog (Santucci et al., 1998; Seddon et al., 2001), the woodmouse (Michaux et al., 2003) and the lesser white-toothed shrew (Taberlet et al., 1998), very little information exists concerning the role of Turkey and Near East regions as refugia for European mammals during glaciations as well as their role as a source for postglacial recolonisers of the Western Palearctic region.

These studies showed that:

- The Oriental regions were probably a refuge for these species during Quaternary glaciations.

- Turkish and Near Eastern populations seem to be more or less genetically differentiated from the European ones. This suggests that they were separated at different historical periods probably following allopatric isolations, which were reinforced by the presence of strong biogeographic barriers such as the Black Sea and the Caucasus. However, these different historical factors as well as the impact of such biogeographic barriers were not well determined, due to sampling bias in the Oriental populations. Therefore, the eastern regions need to be examined more thoroughly.

- The three studied species do not seem to have recolonised Northern Europe from Oriental populations after the last ice age, probably because of the presence of the Black Sea and the Caucasus, but also because they were probably prevented by the more rapid expansion of the Iberian, Italian or Balkan genomes, that filled the northern areas first.

In order to contribute to a better knowledge of the phylogeography of European mammals, a small rodent, the yellow-necked fieldmouse (Apodemus flavicollis), has been studied all over the Western Palearctic region, with a particular emphasis on Turkey and the Near East. It has several advantages for phylogeographic studies. This species is a forest species that has been present in the Western Palearctic region for the past three millions years (My) (Michaux and Pasquier, 1974). Therefore, like the forests, it probably survived during the Quaternary glaciations through important fluctuations in its distribution area. The yellow-necked fieldmouse is relatively common, easy to catch and widespread all over the Western Palearctic region as well as in the Near East regions. Finally, the evolutionary history of the genus Apodemus is well known (Michaux and Pasquier, 1974; Michaux et al., 1997; Michaux et al., 2002; Serizawa et al., 2000; Suzuki et al., 2000), this genus being well represented in the fossil data. Therefore, calibration of a molecular clock is possible for this genus.

\section{Material and methods}

\subsection{Biological material}

A total of 124 A. flavicollis coming from 53 localities widespread throughout their distribution area have been analysed (Table 1, Fig. 1).

\subsection{Laboratory methods}

DNA was extracted from ethanol-preserved tissue following Sambrook et al. (1989). Tissues were taken from the Apodemus tissue collection of J.R. Michaux (JRM-numbers) and the mammal tissue collection housed at the Institut des Sciences de l'Evolution de Montpellier (Catzeflis, 1991; T-numbers).

A large portion of the cytochrome $b(972 \mathrm{bp})$ was amplified using the universal PCR primers L7 (5'-A CCAATGACATGAAAAATCATCGTT- $3^{\prime}$ ) and H16 (5'-A CATGAATYGGAGGYCAACCWG-3') (Kocher et al., 1989). Amplification reactions were carried out in $2 \times 50 \mu \mathrm{l}$ volumes including $25 \mu \mathrm{l}$ of each $2 \mu \mathrm{M}$ primer, $20 \mu \mathrm{l}$ of $1 \mathrm{mM}$ dNTP, $10 \mu \mathrm{l}$ of $10 \times$ reaction buffer, $10 \mu \mathrm{l}$ of purified water, and $0.2 \mu 1$ of $5 \mathrm{U} / \mu 1$ Promega Taq DNA polymerase. Approximately $200 \mathrm{ng}$ of DNA extract was used per PCR amplification. Amplifications were performed in a Labover PTC100 thermal cycler employing 33 cycles $\left(20 \mathrm{~s}\right.$ at $94^{\circ} \mathrm{C}, 30 \mathrm{~s}$ at $50^{\circ} \mathrm{C}$, and $1 \mathrm{~min} 30 \mathrm{~s}$ at $68^{\circ} \mathrm{C}$ ) with a final extension cycle of $10 \mathrm{~min}$ at $68^{\circ} \mathrm{C}$. PCR products were purified using the Ultrafree DA Amicon kit (Millipore). Both strands were sequenced using a Bigdye terminator (Applied Biosystems) sequencing kit and run on an ABI 310 (Applied Biosystems) automated sequencer.

\subsection{Sequence alignment}

Previously published (Michaux et al., 2003) cytochrome $b$ sequences for $A$. flavicollis $(n=3$ : $\mathrm{ABO} 32853$, AF159392, and AF127539), Apodemus sylvaticus $(n=2$ : AJ311148 and AJ311149), and Apodemus mystacinus $(n=2:$ AJ311146 and AJ311147) were downloaded from GenBank (see Table 1) and aligned with the new sequences using the ED editor (MUST package, Philippe, 1993).

\subsection{Sequence analyses}

The aligned sequences were analysed by distance (neighbour joining, NJ; Saitou and Nei, 1987) and maximum parsimony (MP) (Fitch, 1971) methods. The distance analyses were performed using the ME criterion, Kimura's 2 parameter (K2P) and General Time Reversible (GTR) models (chosen with Modeltest 3.0, Posada and Crandall, 1998). These analyses were developed assuming a gamma distribution for substitution rates 
Table 1

Geographic distribution and references of Apodemus tissues

\begin{tabular}{|c|c|c|c|c|}
\hline Geographic origin & & $\begin{array}{l}\text { Total number } \\
\text { of animals }\end{array}$ & $\begin{array}{l}\text { Sample symbols } \\
\text { (see Figs. } 1-3 \text { ) }\end{array}$ & $\begin{array}{l}\text { Tissue sample or GenBank accession } \\
\text { numbers }\end{array}$ \\
\hline \multicolumn{5}{|l|}{ A. flavicollis } \\
\hline Austria & Vorarlberg & 3 & A & JRM-202 to JRM-204 \\
\hline Belarus & Berezina Biosphere reserve & 3 & Bel & JRM-313 to JRM-315 \\
\hline Belgium & Ardennes & 1 & $\mathrm{~B}$ & JRM-332 \\
\hline \multirow[t]{2}{*}{ Czech Republic } & Kašperské & 4 & $\mathrm{CZ1}$ & JRM-373, JRM-377, JRM-378, JRM-379 \\
\hline & Nové Mlyný, Béeclav (Bohemia) & 1 & $\mathrm{CZ2}$ & JRM-255 \\
\hline Estonia & Tallin & 2 & Es & JRM-316, JRM348 \\
\hline \multirow[t]{4}{*}{ France } & Allier & 2 & $\mathrm{~F} 1$ & JRM-343, JRM-344 \\
\hline & Serandon (Corrèze) & 2 & $\mathrm{~F} 2$ & JRM-394, JRM-395 \\
\hline & Py Mantet (Pyrénées-Orientales) & 5 & F3 & JRM-278 to JRM-282 \\
\hline & Normandie & 1 & F4 & JRM-1026 \\
\hline Germany & Bielefeld & 1 & G1 & JRM-207 \\
\hline \multirow[t]{4}{*}{ Greece } & Macedonia region & 4 & Gr1 & JRM-217, JRM-219, JRM-220, JRM-492 \\
\hline & Peloponnesus & 6 & Gr2 & JRM-216, JRM-481 to JRM-485 \\
\hline & Epirus & 2 & Gr3 & JRM-222, JRM-485 \\
\hline & Mt Olympus & 8 & Gr4 & $\begin{array}{l}\text { JRM-460, JRM-701, JRM-704, JRM-706 } \\
\text { to JRM-8, JRM-710, JRM-11 }\end{array}$ \\
\hline Hungary & Debrecen & 1 & $\mathrm{Hu}$ & JRM-307 \\
\hline Iran & Horamabad & 2 & $\mathrm{Ir}$ & JRM-250, JRM-251 \\
\hline Israel & Mt Carmel & 2 & Is & JRM-252, JRM-253 \\
\hline \multirow[t]{3}{*}{ Italy } & Grosseto (Toscania) & 1 & I1 & JRM-175 \\
\hline & Aspromonte (Calabria) & 3 & $\mathrm{I} 2$ & JRM-192 to JRM-194 \\
\hline & Penne (Abruzzo) & 2 & $\mathrm{I} 3$ & JRM-200, JRM-298 \\
\hline Lithuania & Unknown & 1 & $\mathrm{Li}$ & JRM-347 \\
\hline \multirow[t]{2}{*}{ Macedonia } & Mt Pellister & 3 & Ma1 & JRM-213, JRM-214, JRM-492 \\
\hline & Bistra & 4 & $\mathrm{Ma} 2$ & JRM-117 to JRM-120 \\
\hline Netherlands & Unknown & 1 & NL & ABO32853 \\
\hline \multirow[t]{4}{*}{ Romania } & Cheile Garlistei & 2 & $\mathrm{R} 1$ & JRM-533, JRM-534 \\
\hline & Piatra Craiului Mont (Natural Parc) & 2 & $\mathrm{R} 2$ & JRM-572, JRM-573 \\
\hline & Guarda & 1 & $\mathrm{R} 3$ & JRM-532 \\
\hline & Saliste & 1 & R4 & JRM-531 \\
\hline \multirow[t]{3}{*}{ Russia } & Samara & 2 & Rul & JRM-405, JRM-408 \\
\hline & Volgograd & 2 & $\mathrm{Ru} 2$ & JRM-287, JRM-288 \\
\hline & Voronezh & 1 & Ru3 & JRM-309 \\
\hline \multirow[t]{2}{*}{ Slovenia } & Skofja & 2 & S11 & JRM-418, JRM-420 \\
\hline & Asan Cesma & 1 & $\mathrm{~S} 12$ & JRM-122 \\
\hline Spain & Eugi (Navarra) & 10 & $\mathrm{E}$ & $\mathrm{T}-2133$ to $\mathrm{T}-2142$ \\
\hline \multirow[t]{2}{*}{ Sweden } & Gotland & 1 & $\mathrm{~S} 1$ & JRM-445 \\
\hline & Uppsala & 2 & $\mathrm{~S} 2$ & JRM-294, JRM-295 \\
\hline \multirow[t]{2}{*}{ Switzerland } & Geneva & 1 & Sw1 & JRM-342 \\
\hline & Constanz & 1 & Sw2 & AF159392 \\
\hline \multirow[t]{11}{*}{ Turkey } & Damar & 1 & Tur1 & JRM-256 \\
\hline & Datca, Marmaria & 2 & Tur2 & JRM-241, JRM-242 \\
\hline & Egridir & 2 & Tur3 & JRM-237, JRM-238 \\
\hline & Safranbolu, zonguldak & 3 & Tur4 & JRM-232 to JRM234 \\
\hline & Thrace & 6 & Tur5 & $\begin{array}{l}\text { JRM-223, JRM-224, JRM-380 } \\
\text { to JRM-382, JRM-230 }\end{array}$ \\
\hline & Olu Deniz fethiye & 2 & Tur6 & JRM-243, JRM-244 \\
\hline & Rize & 2 & Tur7 & JRM-1360, JRM-1363 \\
\hline & Uludag, Bursa & 2 & Tur8 & JRM-1362, JRM-1364 \\
\hline & Efirli, Ordu & 1 & Tur9 & JRM-1367 \\
\hline & Caycuma, zonguldak & 2 & Tur10 & JRM-1365, JRM-1369 \\
\hline & Belsehir & 2 & Tur11 & JRM 1361, JRM-1366 \\
\hline \multirow[t]{2}{*}{ Ukraine } & Southern Bug & 1 & U1 & $\mathrm{T}-855$ \\
\hline & Tchernobyl & 1 & $\mathrm{U} 2$ & AF127539 \\
\hline Yugoslavia & Susarra (Vojvodine) & 3 & $\mathrm{Y}$ & JRM-178 to JRM-180 \\
\hline \multicolumn{5}{|l|}{ A. sylvaticus } \\
\hline Italy & Latium & 1 & & AJ311148 \\
\hline France & Pyrénées-Orientales & 1 & & AJ311149 \\
\hline \multicolumn{5}{|l|}{ A. mystacinus } \\
\hline Syria & & 1 & & AJ311146 \\
\hline Greece & & 1 & & AJ311147 \\
\hline
\end{tabular}




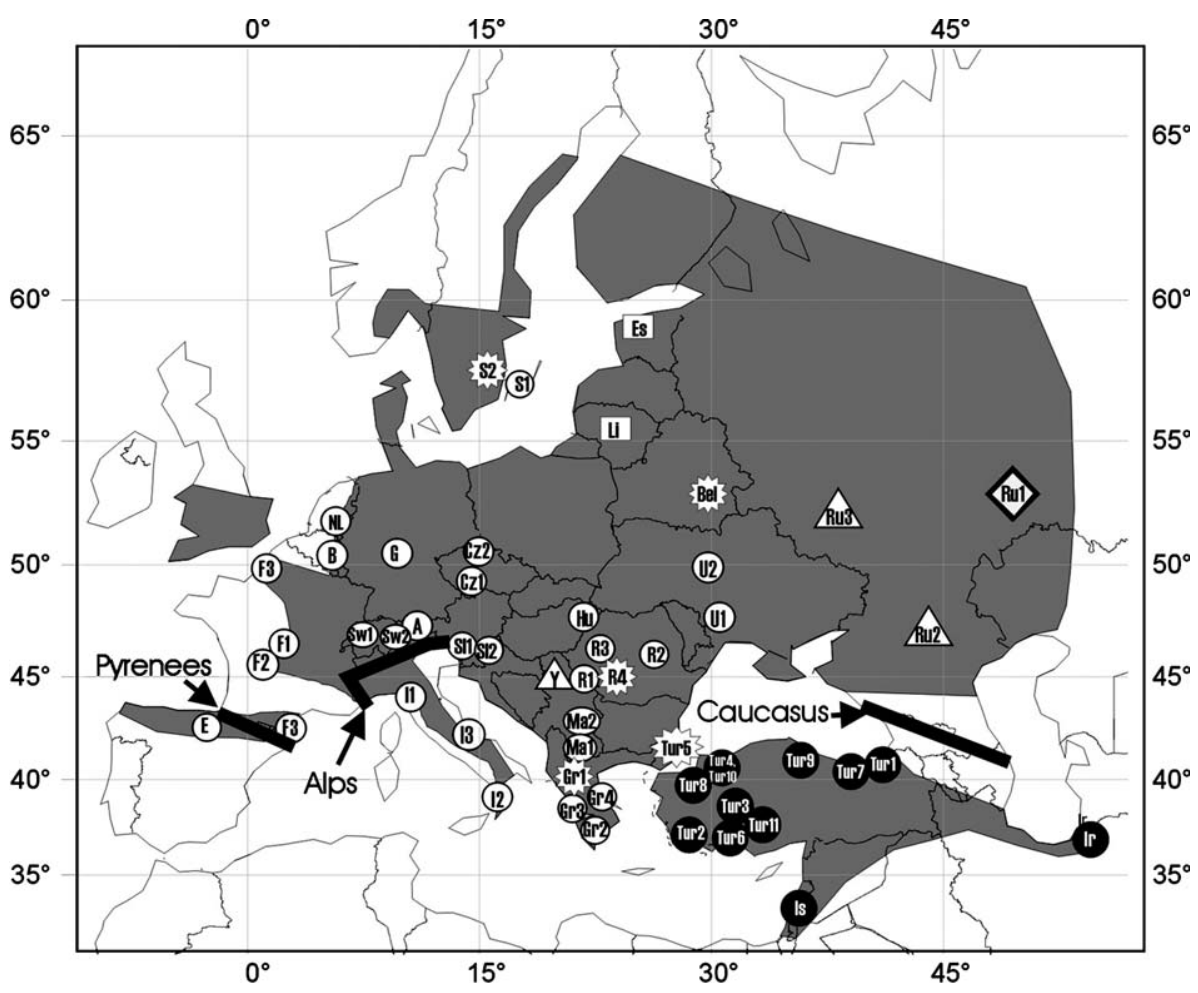

Fig. 1. Geographic distribution of the A. flavicollis samples. The shaded zones correspond to the distribution area of this species [as described by Schilling et al. (1986), Zagorodnyuk et al. (1997), and Mezhzherin (1997)]. Thick lines correspond to the main biogeographic barriers: the Pyrenees, the Alps, and the Caucasus. White circles, squares, triangles, and black circles correspond to clade 1a; $1 \mathrm{~b}, 1 \mathrm{c}$, and 2 , respectively. White stars and diamond shapes correspond to localities where haplotypes from the clades $1 \mathrm{a}$ and $1 \mathrm{~b}$ or from $1 \mathrm{~b}$ and $1 \mathrm{c}$ are mixed, respectively. See Table 1 for locality symbols.

across sites, where the parameter alpha (Yang, 1996) and the proportion of invariant sites (I) was estimated with the maximum-likelihood method assuming the GTR phylogeny using PAUP 4.0b8 (Swofford, 1998). The MP analyses was performed using the following options: heuristic search, TBR branch swapping and Maxtrees $=1000$ (Swofford, 1998). The robustness of inferences was assessed by bootstrap resampling (BP) (Felsenstein, 1985) (1000 random repetitions).

A minimum spanning network was constructed using the MINSPNET algorithm available in the Arlequin 2.0 program (Schneider et al., 2000). The program TCS (Clement et al., 2000) was also used to construct a network. Nucleotide diversity, $\pi$, was estimated using the DNASP program (Rozas and Rozas, 1997). The "mismatch distribution" of substitutional differences between pairs of haplotypes was calculated within the main genetic lineages (clades 1a, 1b, 1c, and 2) and compared with a fit to the Poisson model using DNASP (Rozas and Rozas, 1997). We used a coalescent approach to validate the patterns of population growth or stability revealed by the mismatch distributions (Emerson et al., 2001). We fitted by maximum likelihood two models assuming either that the population was stable through time, or that it grew (or declined) exponentially (Kuhner et al., 1995, 1998).
Since both models are nested, they were compared with a likelihood-ratio test which follows a $\chi^{2}$ distribution with one degree of freedom (there is an additional parameter in the latter model). This analysis was performed with programs Coalesce and Fluctuate from the Lamarc package (http://evolution.genetics. washington.edu/lamarc.html). A model of DNA evolution with a transition/transversion ratio equal to 2 was used with the empirical base frequencies (the results were actually not sensitive to this last parameter as they were similar when we assumed that the base frequencies were equal to 0.25 ). The programs were run several times with different numbers of short and long Markov chains in order to check the consistency of the estimated parameters. The other parameters (THETA with Coalesce, and THETA and the population growth rate with Fluctuate) were allowed to vary, and were estimated at the maximum likelihood. The likelihoodratio test was computed with twice the difference in the log-likelihoods provided by both programs: the null hypothesis being that the population was stable. This analysis was done separately for the four clades (1a, $1 \mathrm{~b}, 1 \mathrm{c}$, and 2).

The population genetic structure was determined by analysing the molecular variance and calculating $\phi_{\text {st }}$ (AMOVA available in Arlequin 2.0; Schneider et al., 
2000). This method estimates the proportion of genetic variation at different hierarchical levels, using information from the geographic distribution of haplotypes and the pairwise distance between them. This analysis was performed at different hierarchical levels: among groups (corresponding to the observed subclades), among populations within each group (23 populations were defined according to geographical and ecological data), and within each population.

Relative-rate tests and an approximate time of divergence between the observed mtDNA lineages were calculated as explained in Michaux et al. (2003). The genetic distance between two different lineages was corrected for ancestral mtDNA polymorphism using the formula of Edwards (1997). Two calibration points derived from paleontological data were used for this analysis. First, the divergence time between A. mystacinus and all the "small" Sylvaemus was estimated at approximately $7 \mathrm{My}$ (Aguilar and Michaux, 1996; Michaux et al., 1997) and second, the divergence between A. sylvaticus and A. flavicollis was estimated to be approximately 4 My old (Michaux and Pasquier, 1974; Michaux J., Pers. Commun.).

\section{Results}

\subsection{Haplotype variations}

We identified 95 haplotypes among the 124 A. Alavicollis cytochrome $b$ sequences (GenBank Accession Nos. AJ605600-AJ605692 + published sequences: ABO32853, AF159392). The complete data matrix comprised these 95 haplotypes as well as two $A$. sylvaticus and two A. mystacinus sequences used as outgroups. Within the $972 \mathrm{bp}$ of the matrix, 203 sites $(21 \%)$ were variable and $121(12 \%)$ were parsimony informative (considering only ingroups). The mean transition to transversion ratio was 3.49 and the nucleotide frequencies were 27.2, 29,0, 31.4, and $12.3 \%$ for $\mathrm{C}, \mathrm{T}, \mathrm{A}$, and $\mathrm{G}$, respectively.

\subsection{Phylogenetic analyses}

The neighbour-joining trees (Fig. 2) obtained using K2P and GTR models were identical and showed that the 95 A. flavicollis haplotypes fell into two major clades: the first one corresponding to all the populations from the European and Russian regions (clade 1) and the second one comprising the animals from Turkey, Near, and Middle East (clade 2). These clades are well supported (BP of $100 \%$ ) and separated by a high degree of genetic divergence $(7.2 \% \mathrm{~K} 2 \mathrm{P}$ genetic distance).

Moreover, three subclades can be observed within the European populations: the first one (subclade 1a) is not well supported (BP of $61 / 53 \%$ ) and comprises individuals from all the Western Palearctic regions including western (France, Belgium...), northern (Sweden), and eastern Europe as far as Ukraine as well as the three Mediterranean peninsulas (Spain-Portugal, Italy, and Balkans). The second one (1b) (BP: $82 / 70 \%$ ) is characterised by specimens from northern Europe (Russia, Estonia, Lithuania, Belarus, and Sweden) and the Balkan region (Greece, Romania, and Western Turkey). The third one (1c) (BP: 100/85\%) corresponds to animals from southern Russia, Romania, and former-Yugoslavia. The genetic divergence between these clades is low: $1.3 \% \mathrm{~K} 2 \mathrm{P}$ distance between $1 \mathrm{a}$ and $1 \mathrm{~b}$ and $1.9 \%$ between $1 \mathrm{a}, 1 \mathrm{~b}$, and $1 \mathrm{c}$.

The MP analyses yielded one most parsimonious tree $(\mathrm{L}=653$ steps; $\mathrm{CI}=0.60 ; \mathrm{RI}=0.84)$ identical to the $\mathrm{NJ}$ tree. The bootstrap values resulting from this analysis are shown in Fig. 2.

The minimum spanning networks (Fig. 3) show similar results with a high differentiation between European (clade 1) and Near and Middle Eastern animals (clade 2) (46 mutational steps). Within the European lineage, almost all the haplotypes are connected together in a large star-like topology (subclade 1a). Subclade 1b is separated from subclade $1 \mathrm{a}$ by 5 mutational steps and subclade $1 \mathrm{c}$ is separated from subclade $1 \mathrm{~b}$ by 9 mutational steps. The network obtained using the TCS program (Clement et al., 2000) gave the same topology. However, as the number of mutational steps between the clades 1and 2 was higher than 13 (methodological limit of the TCS program), it was impossible to connect them using this program. At least, it confirmed that these clades are very differentiated.

\subsection{Nucleotide diversity and genetic structure}

To assess whether genetic diversity was higher within the potential refuge regions (Iberian peninsula + southern France, Italy + Balkans, southern Russia) as compared to northern populations, the samples were separated into different subgroups corresponding to these regions, then nucleotide and haplotype diversities were calculated for each of them (see Table 2).

The results indicate that the Italo-Balkanic region is characterised by the highest nucleotide diversity $(\pi=0.015)(p<0.05)$ as compared to the populations from all the other regions. The animals from south western Europe (Iberian peninsula + southern France) are the less genetically diversified $(\pi=0.0054)$.

The AMOVA shows that the majority of the total mtDNA variation (79.7\%) observed within A. flavicollis is distributed among the two genetic groups whereas a low percentage of this variation $(3.8 \%)$ is observed among populations within the main clades

A signature of population growth (i.e., a bell-shaped distribution) is clearly evident in the distribution of pairwise distribution within clade 2 and subclade 1a (Fig. 4). Moreover, the coalescence analysis rejects the 


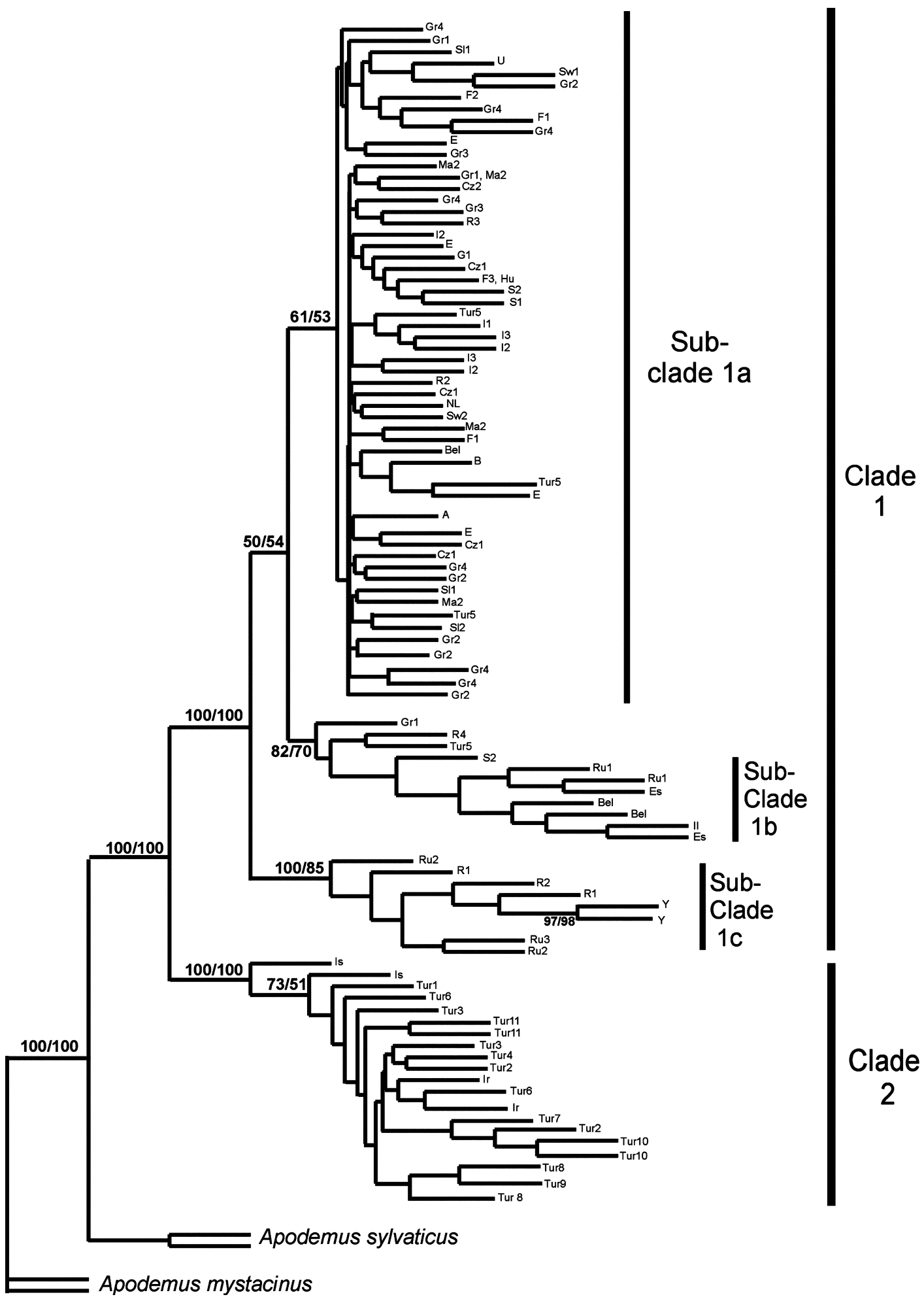

Fig. 2. Neighbour-joining tree for the 95 yellow-necked fieldmouse mtDNA haplotypes. Numbers above or below the branches correspond to bootstrap support above 50\% obtained in the NJ and MP analyses, respectively. Geographic origins of haplotypes are given (see Table 1 and Fig. 1).

null hypothesis of a stable population for these clades (Table 3). Although the same tendency can be observed in the subclades $1 \mathrm{~b}$ and $1 \mathrm{c}$, it is less clear. This can be explained by a too low sample size ( 7 individuals for each).

\subsection{Divergence time}

The relative rate tests indicate no significant rate heterogeneity (both $K_{\mathrm{s}}$ and $K_{\mathrm{a}}$ ) for cytochrome $b$ between the different $A$. flavicollis lineages. 


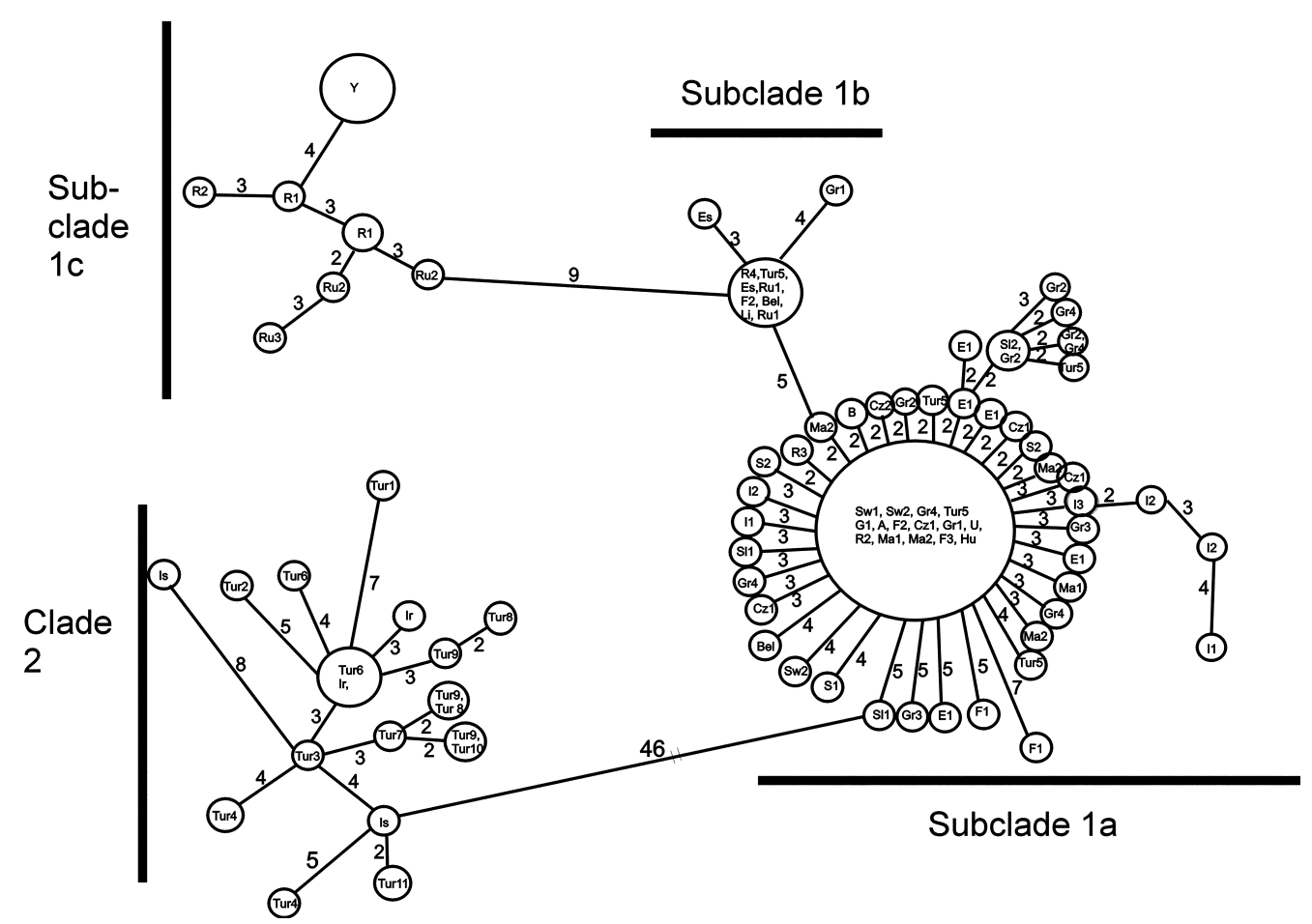

Fig. 3. Minimum spanning network constructed using mitochondrial cytochrome $b$ gene sequences of A. flavicollis. Geographic origins (see Table 1 and Fig. 1) are indicated. To simplify, haplotypes separated by only one mutational step have been combined. Numbers correspond to the mutational steps observed between haplotypes.

Table 2

Genetic variability observed within potential refuge regions of A. flavicollis

\begin{tabular}{|c|c|c|c|c|c|c|c|}
\hline & Sample size & $\begin{array}{l}\text { Number of } \\
\text { haplotypes }\end{array}$ & $\begin{array}{l}\text { Genetic divergence within } \\
\text { each clade }(\% \mathrm{~K} 2 \mathrm{P} \\
\text { distance) }\end{array}$ & $\begin{array}{l}\text { Nucleotide } \\
\text { diversity }(\pi)\end{array}$ & $\begin{array}{l}\text { Standard } \\
\text { deviation }\end{array}$ & $\begin{array}{l}\text { Haplotype } \\
\text { diversity }(h)\end{array}$ & $\begin{array}{l}\text { Standard } \\
\text { deviation }\end{array}$ \\
\hline \multicolumn{8}{|l|}{ Clade 1} \\
\hline Balkans + Italy & 45 & 35 & 0.012 & 0.015 & 0.0011 & 0.988 & 0.007 \\
\hline $\begin{array}{l}\text { Iberian peninsula } \\
+ \text { southern France }\end{array}$ & 15 & 5 & 0.5 & 0.0054 & 0.00110 & 0.986 & 0.096 \\
\hline $\begin{array}{l}\text { Western, northern } \\
+ \text { central Europe }\end{array}$ & 31 & 26 & 0.0078 & 0.0075 & 0.0015 & 0.991 & 0.046 \\
\hline Ukraine + Russia & 10 & 9 & 0.011 & 0.0092 & 0.0014 & 0.952 & 0.096 \\
\hline \multicolumn{8}{|l|}{ Clade 2} \\
\hline $\begin{array}{l}\text { Turkey + Near and } \\
\text { Middle East }\end{array}$ & 23 & 20 & 0.009 & 0.0085 & 0.00085 & 0.99 & 0.028 \\
\hline
\end{tabular}

The mean K2P distance between $A$. mystacinus and the species $A$. flavicollis - A. sylvaticus that diverged $7 \mathrm{My}$ ago is $18.2 \%$. The distance between A. flavicollis and A. sylvaticus that diverged $4 \mathrm{My}$ ago is $11.4 \%$. These values correspond to a rate of $2.6-2.85 \% \mathrm{~K} 2 \mathrm{P}$ distance per million years. Therefore, taking into account the correction for ancestral mtDNA polymorphism, the separation time between clades 1 and 2 dates back to 2.2-2.4 (confidence intervals (CI): 0.0015-0.0013) My, the one between subclades $1 \mathrm{a}, 1 \mathrm{~b}$, and $1 \mathrm{c}$ to $0.5-0.6$ (CI: 0.0024-0.0022) My ago and the one between subclades 1a and 1b, to 0.4 (CI: 0.0011) My ago.

\section{Discussion}

\subsection{Association of geographic structure and historical factors}

The distance, maximum parsimony and network analyses clearly show that $A$. flavicollis populations are split into two main genetic clades that have nonoverlapping geographic distributions and are separated by a high level of genetic divergence $(7.2 \% \mathrm{~K} 2 \mathrm{P}$ genetic distance). This geographic structure is highly supported since $79.7 \%$ of the total mtDNA variation (AMOVA 


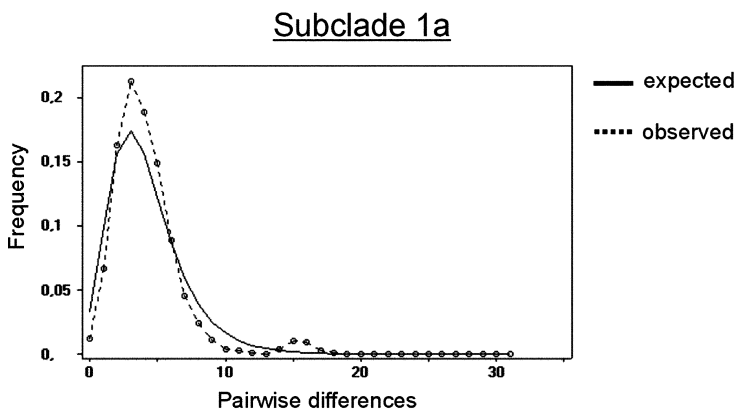

Subclade 1c

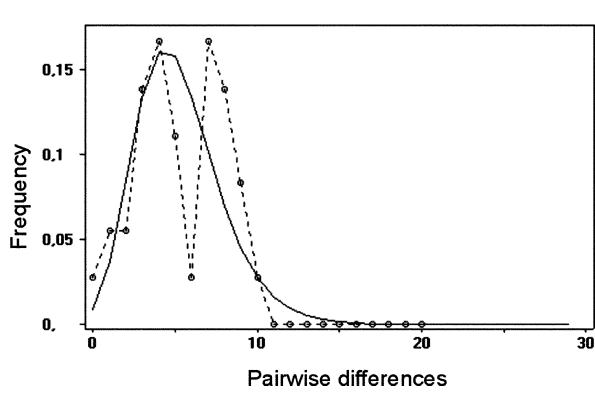

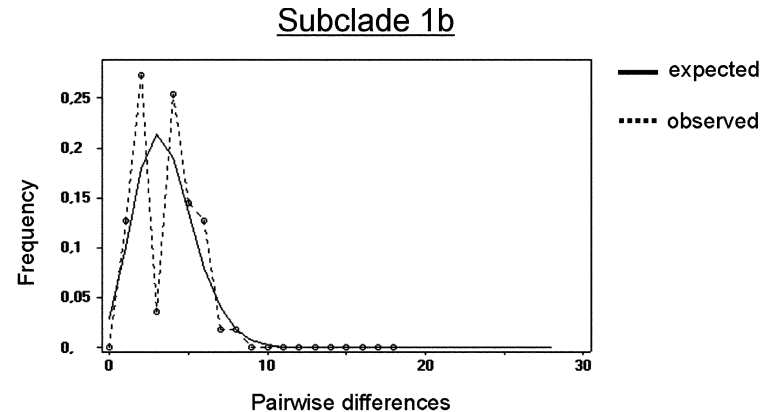

Clade 2
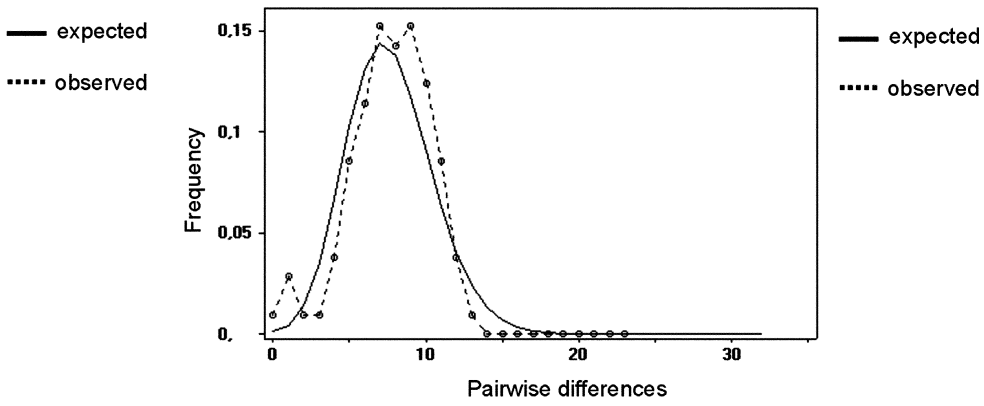

Fig. 4. Mismatch distribution for mtDNA types from the four major A. flavicollis genetic clades. The expected frequency is based on a population growth-decline model (for the clades $1 \mathrm{a}, 1 \mathrm{~b}, 1 \mathrm{c}$, and 2 , respectively: $\theta_{\text {initial }}=0,2.4,0$, and $0, \theta_{\text {final }}=1000, \tau=4.4,9.2,2.9$, and 1.5 ), determined using the DNASP v3.5 program (Rozas and Rozas, 1997) and is represented by a continuous line. The observed frequency is represented by a dotted line.

Table 3

Results of the coalescence analysis on the four main genetic clades of A. flavicollis

\begin{tabular}{|c|c|c|c|c|}
\hline \multirow[t]{2}{*}{ Sub-clades } & \multicolumn{4}{|c|}{ Log-likelihood } \\
\hline & $\begin{array}{l}\text { Stable popu- } \\
\text { lation model }\end{array}$ & $\begin{array}{l}\text { Exponential } \\
\text { change model }\end{array}$ & $\chi^{2}$ & $P$ \\
\hline $\begin{array}{l}\text { Western Palearctic } \\
\text { region (1a) }\end{array}$ & -0.2444 & 1.8731 & 4.235 & 0.040 \\
\hline $\begin{array}{l}\text { Balkans + Northern } \\
\text { Europe (1b) }\end{array}$ & 0.0141 & 1.0592 & 2.090 & 0.148 \\
\hline $\begin{array}{l}\text { Balkans + Southern } \\
\text { Russia (1c) }\end{array}$ & 0.0026 & 0.1117 & 0.218 & 0.640 \\
\hline $\begin{array}{c}\text { Turkey }+ \text { Near and } \\
\text { Middle East (2) }\end{array}$ & -0.0053 & 1.7938 & 3.598 & 0.058 \\
\hline
\end{tabular}

analysis) is distributed among the two genetic groups. In contrast, as already observed on the phylogenetic tree, a smaller percentage of variability exists among populations within each of these clades $(3.8 \%$ of total mtDNA variation).

The first clade corresponds to the populations from Turkey, Israel, and Iran whereas the second one comprises all the Western Palearctic populations, from the Iberian Peninsula in the west, to southern Russia (Samara) in the east and Estonia in the north. This strong geographic structure corresponds to the first category of phylogeographic models defined by Avise (2000) (deep gene tree, major lineages allopatric). As already proposed for the woodmouse (A. sylvaticus) (Michaux et al., 2003), this structure could be explained by isolation of two yellow-necked fieldmice groups in two different refugia (one in the Near East region, the other one in a Mediterranean Peninsula) during one of the first Quaternary climatic oscillations. Indeed, the molecular clock analysis shows that the separation between these two groups appeared between the TertiaryQuaternary transition, between 2.2 and $2.4 \mathrm{My}$ ago, when rapid alterations of the climate were observed throughout Europe (Fauquette et al., 1998). The vegetation followed these climatic changes, with the appearance of more open landscape with steppe, foreststeppe in many North European regions (Borisova, 1993; Fauquette et al., 1998, 1999) and as the yellownecked mouse is mainly adapted to forest habitats, it probably survived to these early glacial periods in southern regions as the Mediterranean peninsula or in the Near East where forest still existed. Interestingly, it is also during this period that the Balkan and Turkish lineages of Erinaceus concolor were separated (Hewitt, 1999).

Three main genetic subclades separated by a low level of genetic divergence (between 1.3 and 1.9\% K2P distance) and overlapping in part of their geographic distribution (i.e., the Balkan region) can be observed within the Western Palearctic group. The divergence time estimated on the basis of two paleontological calibration points, indicates a separation time of 0.4-0.6 My between the ancestral haplotypes which led to these three subclades. Therefore, it appears that the 
intraspecific structure of these A. flavicollis lineages developed later, during middle to late quaternary.

These early and recent periods of intraspecific differentiation observed in A. flavicollis are highly divergent from those observed in its sister species, the woodmouse, A. sylvaticus, which date back to the Middle of the Early Pleistocene, 1.5-1.6 My ago (Michaux et al., 2003). This tends to show that even closely related species can have strongly different phylogeographic histories.

\subsection{Refuge regions and postglacial recolonisations}

As the Turkish and Near East populations of A. flavicollis are well separated from European ones, it can be assumed that these Oriental regions were not colonised until recently by European animals and therefore, these regions were a long-term refuge for the species. This result is consistent with the hypothesis of Hewitt (1999) who noted that Turkey was probably an important refuge for European species. The bell-shaped curve in the mismatch distribution analysis (Fig. 4) as well as the results obtained in the coalescent approach (Table 3) suggest a scenario of recent expansion for this population, probably following a population bottleneck. However, the heterogeneous topology of clade 2 (Fig. 3) as compared to the main European subclade 1a, associated with high values for Haplotype diversity $(h)$ and the relatively high value for nucleotide diversity $(\pi)$ (Table 2), suggest that this genetic bottleneck was less severe than in Europe. The recent expansion of A. flavicollis in Turkey and Near East is probably associated to the important vegetation changes, which characterised this region for the last 20,000 years. Indeed, during the last ice age, Turkey was mainly covered by steppic vegetation, which changed progressively into coniferous forest and wooded steppe during the last 10,000 years (Brown and Gibson, 1983; Van Zeist et al., 1975). This probably allowed forest species such as A. flavicollis, to recolonise Oriental regions from glacial refuges, which are presently difficult to localise. However, according to pollen data (Brown and Gibson, 1983), they could correspond to western coastal regions of Turkey and Near East.

Our results suggest that the Oriental population did not recolonise North European or Russian regions. This is probably linked to the presence of strong biogeographic barriers such as the Black Sea and the Caucasus which prevented contact between Palearctic and Oriental animals. These barriers seem to be also effective for other species, as the Black alder (Alnus glutinosa), the Hedgehog (E. concolor), the lesser white toothed shrew (Crocidura suaveolens) or the broad toothed fieldmouse (A. mystacinus) (Hewitt, 1999; Michaux, unpubl. data; Taberlet et al., 1998). On the contrary, for other species such as the toad Bombina bombina (Szymura et al., 2000), the newt Triturus sp. (Taberlet et al., 1998), the grasshopper Chorthippus parallelus (Hewitt, 1999), and the woodmouse A. sylvaticus (Michaux et al., 2003), the Turkish populations seem to be closely related to the Balkans ones suggesting a recent separation or frequent gene flow between these populations, probably during the Quaternary ice ages when the Marmara Sea was replaced by dry lands (Tzedakis et al., 1997). Therefore, why did the Oriental populations of $A$. flavicollis not colonise the Balkan regions during these periods? An answer could be found in the fact that yellow-necked fieldmice are already established in the Balkan region since a long time (Aguilar and Michaux, unpubl. data) and that they could have prevented the colonisation of new invaders. Indeed, once established, resident rodents often aggressively exclude newcomers (Granjon and Cheylan, 1989). A new sampling of populations living East of the Caspian Sea (Turkmenistan, Uzbekistan, Kazakhstan...) would be interesting to determine a possible contact zone between the Palearctic and Oriental genetic lineages of A. flavicollis in these regions.

Within the European lineage, as predicted by the expansion/contraction model (Nichols and Hewitt, 1994; Santucci et al., 1998), the analysis of nucleotide diversity (Table 2) suggests that the Italo-Balkan region was a refuge for $A$. flavicollis. Indeed, these populations are characterised by genetic diversity significantly higher $(\pi=0.015, p<0.05)$ than in northern, eastern or western populations. This is also verified for each of the three genetic subclades (data not shown). Therefore, these subclades probably survived the last Quaternary glaciations in three independent Balkanic refuges where they diverged separately. They merged later all over the Palearctic region during interglacial periods.

On the contrary, the population of the potential southwestern refuge (Iberian peninsula and southern France) has the lowest level of nucleotide diversity and, in contrast to A. sylvaticus, does not possess specific haplotypes as compared to other regions. This can be explained by a recent colonisation of this region from the Balkan refuge population. Indeed, as proposed by Hewitt (1999) and Avise (2000), a rapid expansion from refugial populations involves serial bottlenecks with progressive loss of allelic diversity resulting in less genetic diversity among populations living in the more recently colonised places. This hypothesis is corroborated by the intermediate level of nucleotide diversity characterising the populations from central and western Europe as well as from northern Europe.

Therefore, it seems that:

- The Iberian peninsula did not constitute a refuge for the focus species during the last glaciation. This is corroborated by paleontological data, which attest the presence of A. flavicollis in this region only from the end of the Lower to the beginning of the Upper Pleistocene (Sese, 1994). 
- Apodemus flavicollis did not survive up to the last glaciation in Western, Eastern and Northern Europe. This hypothesis is also confirmed by paleontological data (Aguilar and Michaux, unpubl. data; Cordy, 1984).

- Three genetic subclades of the yellow-necked fieldmouse surviving in the Balkan region recolonised the main part of the Western Palearctic region after the last ice age. This scenario of expansion is corroborated by a bell-shaped curve in the mismatch distribution analysis for the three genetic subclades (Fig. 4) as well as enzymatic data (Filippucci et al., 2002). Moreover, the star-like topology characterising the main genetic subclade (1a) suggests that this expansion was probably very rapid and explosive for this group. It recolonised almost all Europe including Western Russia and took place after a bottleneck which had probably lowered its ancestral genetic diversity (Avise, 2000).

\section{Conclusions}

This study supports the existence of two main refuges for the yellow-necked mouse, the first one in the Balkan region; the second one in the Near East region. All the Western Palearctic area was recolonised from the Balkan population whereas the Oriental populations were probably blocked by the Black Sea and the Caucasus as well as by the presence of established populations of fieldmice since a long time in the Balkans. The Oriental population is genetically very differentiated from the European and Russian populations and could be described as a particular subspecies. However, before a definitive conclusion concerning its taxonomic status, it would have to be verified on the basis of other markers such as nuclear genes. Indeed, a previous genetic study based on enzymatic data (Filippucci et al., 2002) tended to show a closer relationship between European and Oriental populations. Finally, our study emphasises the importance of Turkey and of the Near and Middle East regions as a refuge for the Palearctic mammals.

\section{Acknowledgments}

We thank Dr. E. Krywko as well as two anonymous reviewers for their helpful comments on the manuscript. We thank François Catzeflis for providing tissue samples from the collection of ethanol preserved tissues of the Institut des Sciences de l'Evolution (Montpellier) and all those people who provided tissue samples of rodent taxa: L. Balciauskas, E. Bellinvia, J. Cassaing, E. Colak, C. Feliu, M.-G. Filippucci, R. Fons, D. Frynta, C. Guillaume, T.S. Hansen, J. Kiili, B. Krystufek, G. Lauters, P. Lymberakis, M. Macholan, S. Morand, D.
Murariu, S. Naidenko, Dr. K. Neumann, C. Nieberding, V. Orlov, M.G. Ramalhinho, M. Sara, D. Sirugue, H. Tegelström, G. Tikhonova, P. Trontelj, V. Vohralik, R. Wolf, and N. Yigit. This work was supported by a Belgian FNRS fellowship to J.R. Michaux (mandat "collaborateur scientifique") and a financial grant of the Belgian FNRS (crédits aux chercheurs, crédits pour brefs séjours à l'étranger to J.R.M. and R.L.). This is contribution ISEM-2004-014 of the Institut des Sciences de l'Evolution de Montpellier (UMR 5554 CNRS).

\section{References}

Aguilar, J.-P., Michaux, J., 1996. The beginning of the age of Murinae (Mammalia: Rodentia) in southern France. Act. Zool. Cracoviensa $39,35-45$.

Avise, J.C., 2000. Phylogeography. The History and Formation of Species. Harvard University Press, Cambridge, MA.

Bilton, D.T., Mirol, P.M., Mascheretti, S., Fredga, K., Zima, J., Searle, J.B., 1998. Mediterranean Europe as an area of endemism for small mammals rather than a source for northwards postglacial colonization. Proc. R. Soc. Lond. B Biol. Sci. 265, 1219-1226.

Borisova, O.K., 1993. Landscape and climate of the South-Central and Southeastern Russian plain during the Pliocene. Abstracts from a USGS workshop, Herndon, Virginia, USA, p. 61.

Brown, J.H., Gibson, A.C., 1983. Biogeography. Mosby (Eds.), St. Louis, USA.

Brunhoff, C., Galbreath, E., Fedorov, V.B., Cook, J.A., Jaarola, M., 2003. Holarctic phylogeography of the root vole (Microtus oеconomus): implications for late quaternary biogeography of high latitudes. Mol. Ecol. 12, 957-968.

Catzeflis, F., 1991. Animal tissue collections for molecular genetics and systematics. Trends Ecol. Evol. 6, 168.

Clement, M., Posada, D., Crandall, K.A., 2000. TCS: a computer program to estimate gene genealogies. Mol. Ecol. 9, 1657-1659.

Cordy, J.M., 1984. Evolution des faunes quaternaires en belgique. In: Cahen, D., Haesaerts, P. (Eds.), Peuples chasseurs de la Belgique préhistorique dans leur cadre naturel. Bruxelles, Belgium, pp. 6777.

Edwards, S.V., 1997. Relevance of microevolutionary processes to higher level molecular systematics. In: Mindell, D.P. (Ed.), Avian Molecular Evolution and Systematics. Academic Press, New York, pp. 251-278.

Emerson, B., Paradis, E., Thébaud, C., 2001. Revealing the demographic histories of species using DNA sequences. Trends Ecol. Evol. 16, 707-716.

Fauquette, S., Guiot, J., Suc, J.P., 1998. A method for climatic reconstruction of the Mediterranean Pliocene using pollen data. Palaeogeogr. Palaeoclimatol. Palaeoecol. 144, 183-201.

Fauquette, S., Clauzon, G., Suc, J.P., Zheng, Z., 1999. A new approach for palaeoaltitude estimates based on pollen records: example of the Mercantour massif (southeastern France) at the earliest Pliocene. Earth Planet. Sci. Lett. 170, 35-47.

Felsenstein, J., 1985. Confidence limits on phylogenies with a molecular clock. Syst. Zool. 34, 152-161.

Filippucci, M.-G., Macholan, M., Michaux, J.R., 2002. Genetic variation and divergence among Apodemus species. Biol. J. Linn. Soc. Lond. 75, 395-420.

Fitch, W.M., 1971. Towards defining the course of evolution: minimum change for a specific tree topology. Syst. Zool. 20, 406416.

Granjon, L., Cheylan, G., 1989. Le sort de rats noirs (Rattus rattus) introduits sur une île, révélé par radiotracking. CRAS, Paris, vol. 309 , pp. 571-575. 
Hewitt, G.M., 1999. Post-glacial recolonisation of European biota. Biol. J. Linn. Soc. Lond. 58, 87-112.

Hewitt, G.M., 2001. Speciation, hybrid zones and phylogeography—or seeing genes in space and time. Mol. Ecol. 10, 537-549.

Jaarola, M., Searle, J., 2002. Phylogeography of field voles (Microtus agrestis) in Eurasia inferred from mitochondrial DNA sequences. Mol. Ecol. 11, 2613-2621.

Kocher, T.D., Thomas, W.K., Meyer, A., Edwards, S.V., Pääbo, S., Illablanca, F.X., 1989. Dynamics of mitochondrial DNA evolution in animals: amplification and sequencing with conserved primers. Proc. Natl. Acad. Sci. USA 86, 6196-6200.

Kuhner, M.K., Yamato, J., Felsenstein, J., 1995. Estimating effective population size and mutation rate from sequence data using Metropolis-Hastings sampling. Genetics 140, 1421-1430.

Kuhner, M.K., Yamato, J., Felsenstein, J., 1998. Maximum likelihood estimation of population growth rates based on the coalescent. Genetics 149, 429-434.

Mezhzherin, S.V., 1997. Revision of mice Genus Apodemus (Rodentia, Muridae) of Northern Eurasia. Vestnik zool. 31, 29-41 (in Russian, with English abstract).

Michaux, J., Pasquier, L., 1974. Dynamique des populations de mulots (Rodentia, Apodemus) en Europe durant le Quaternaire. Premières données. Bull. Soc. Geol France 7, 431-439.

Michaux, J., Aguilar, J.-P., Montuire, S., Wolff, A., Legendre, S., 1997. Les Murinae (Rodentia, Mammalia) néogènes du Sud de la France: évolution et paléoenvironnements. Geobios 20, 379-385.

Michaux, J.R., Chevret, P., Filippucci, M.-G., Macholan, M., 2002. Phylogeny of the genus Apodemus with a special emphasis to the subgenus Sylvaemus using the nuclear IRBP gene and two mitochondrial markers: cytochrome $b$ and 12s rRNA. Mol. Phylogenet. Evol. 23, 123-136.

Michaux, J.R., Magnanou, E., Paradis, E., Nieberding, C., Libois, R.M., 2003. Mitochondrial phylogeography of the woodmouse (Apodemus sylvaticus) in the Western Palearctic region. Mol. Ecol. 12, 685-697.

Nichols, R.A., Hewitt, G.M., 1994. The genetic consequences of long distance dispersal during colonisation. Heredity 72, 312-317.

Philippe, H., 1993. MUST, a computer package for Management Utilities for Sequences and Trees. Nucleic Acids Res. 21, 5264 5272.

Posada, D., Crandall, A., 1998. MODELTEST: testing then model of DNA substitution. Bioinform. Appl. Note 14, 817-818.

Rozas, J., Rozas, R., 1997. DNASP, version 2.0: a novel software package for extensive molecular population genetic analysis. Comput. Appl. Biosci. 13, 307-311.
Saitou, N., Nei, M., 1987. The neighbor-joining method: a new method for reconstructing phylogenetic trees. Mol. Biol. Evol. 4, 406-425.

Sambrook, J., Fritsch, E.F., Maniatis, T., 1989. Molecular Cloning: A Laboratory Manual. Cold Spring Harbor Laboratory, Cold Spring Harbor, NY.

Santucci, F., Emerson, B.C., Hewitt, G.M., 1998. Mitochondrial DNA phylogeography of European hedgehogs. Mol. Ecol. 7, 1163-1172.

Schilling, D., Singer, D., Diller, H., 1986. Guide des Mammifères d'Europe. Delachaux and Niestlé, Paris.

Schneider, S., Roessli, D., Excoffier, L., 2000. Arlequin, Version 2.0: a software for population genetic data analysis. Genetics and Biometry Laboratory, University of Geneva, Geneva.

Seddon, J.M., Santucci, F., Reeve, N.J., Hewitt, G.M., 2001. DNA footprints of European hedgehogs, Erinaceus europaeus and E. concolor: Pleistocene refugia, postglacial expansion and colonization routes. Mol. Ecol. 10, 2187-2198.

Serizawa, K., Suzuki, H., Tsuchiya, K., 2000. A phylogenetic view on species radiation in Apodemus inferred from variation of nuclear and mitochondrial genes. Biochem. Genet. 38, $27-41$.

Sese, C., 1994. Paleoclimatical interpretation of the Quaternary small mammals of Spain. Geobios 27, 753-767.

Suzuki, H., Tsuchiya, K., Takezaki, N., 2000. A molecular phylogenetic framework for the Ryuyku endemic rodents Tokudaia osimensis and Diplothrix legata. Mol. Phylogenet. Evol. 15, 15-24.

Swofford, D.L., 1998. PAUP*. Phylogenetic Analysis Using Parsimony ( $*$ and Other Methods). Version 4.0b. Sinauer Associates, Sunderland, MA.

Szymura, J.M., Uzell, T., Spolsky, C., 2000. Mitochondrial DNA variation in the hybridizing fire-bellied toads Bombina bombina and B. variegata. Mol. Ecol. 9, 891-899.

Taberlet, P., Fumagalli, L., Wust-Saucy, A.G., Cosson, J.F., 1998. Comparative phylogeography and postglacial colonization routes in Europe. Mol. Ecol. 7, 453-464.

Tzedakis, P.C., Andrieu, V., de Beaulieu, J.L., Crwhurst, S., Follieri, M., Hooghiemstr, H., 1997. Comparison of terrestrial and marine records of changing climate of the last 500,000 years. Earth Planet. Sci. Lett. 150, 171-176.

Van Zeist, W., Woldring, H., Stapert, D., 1975. Late quaternary vegetation and climate of Southwestern Turkey. Palaeohistoria 17, 53-143.

Yang, Z., 1996. Among-site rate variation and its impact on phylogenetic analyses. Trends Eco.1 Evol. 11, 367-372.

Zagorodnyuk, I.V., Boyeskorov, G.G., Zykov, O.E., 1997. Variation and taxonomic status of the steppe forms of genus Sylvaemus "sylvaticus" (falzfeini-fulvipectus-hermonensis-arianus). Vestnik Zool. 31, 37-56 (in Russian, with English abstract). 